


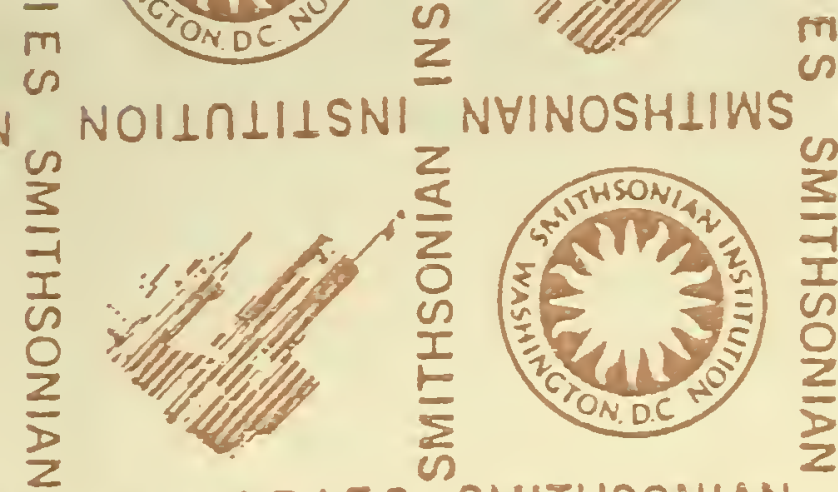

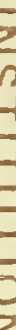

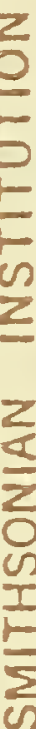
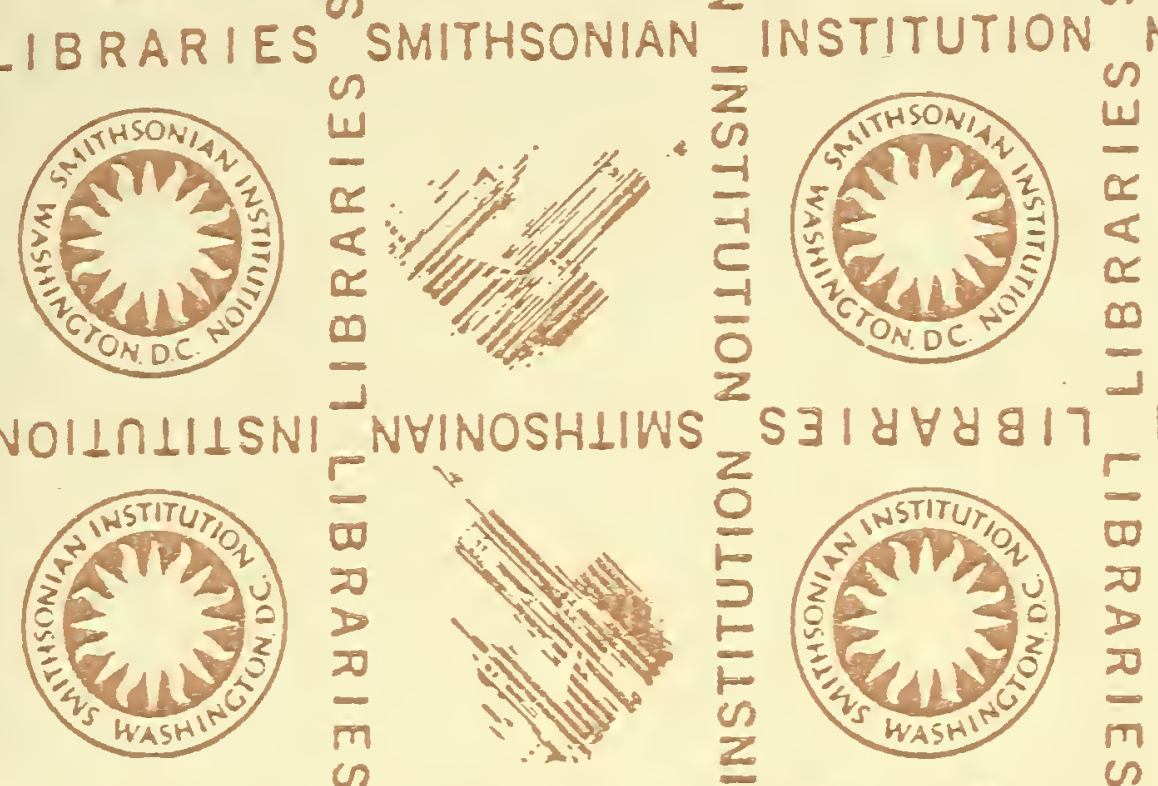

IBRARIES SMITHSONIAN
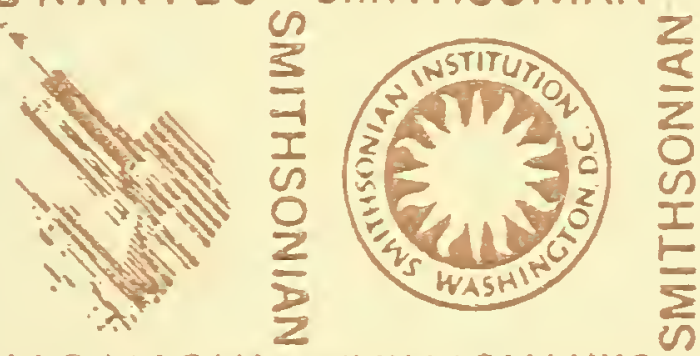

NOILNLILSNI
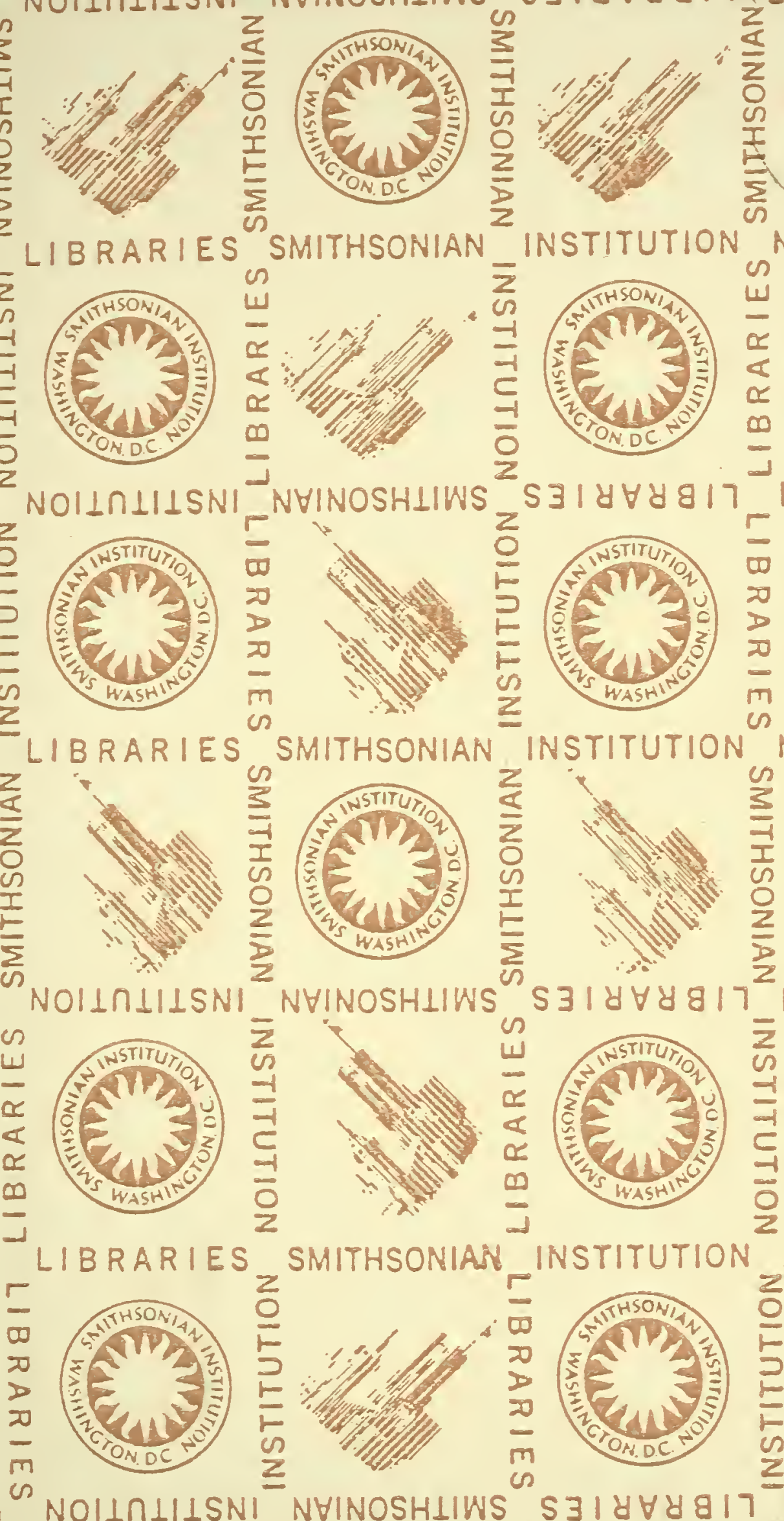

INSTITUTION
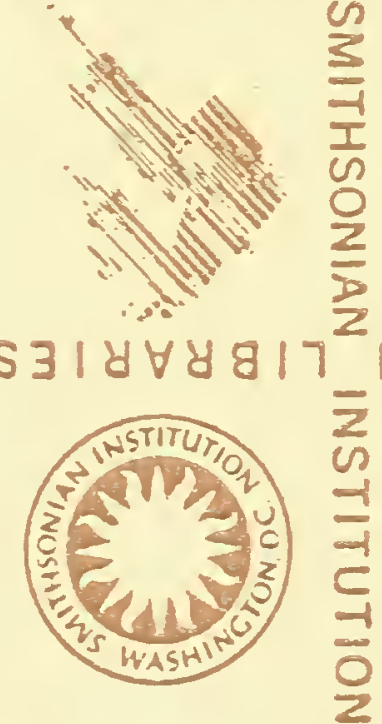
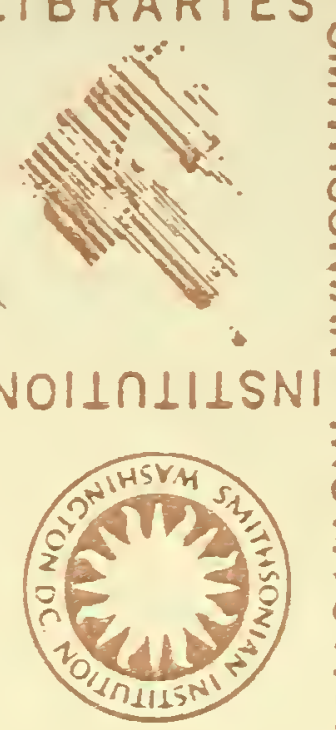

2

nnu1
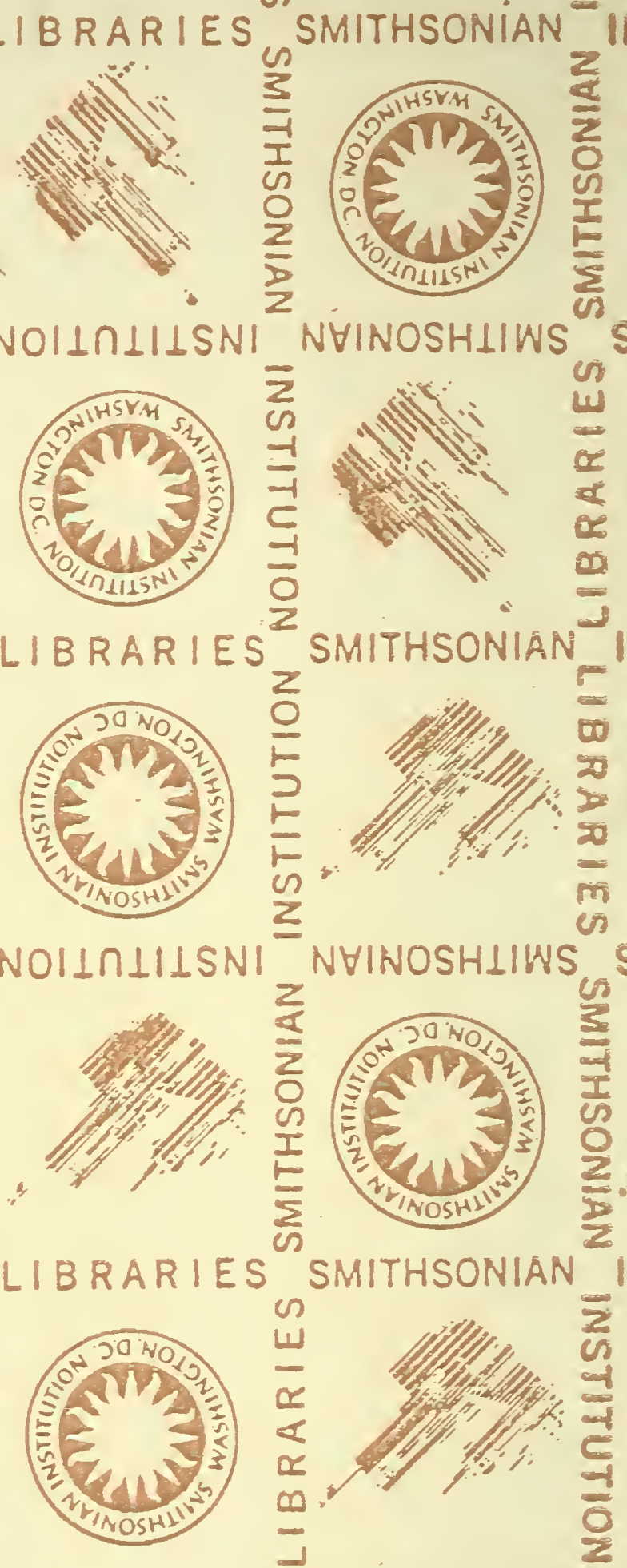

$\frac{1}{2}$

NOILIIISNI NHINOSHLIWS
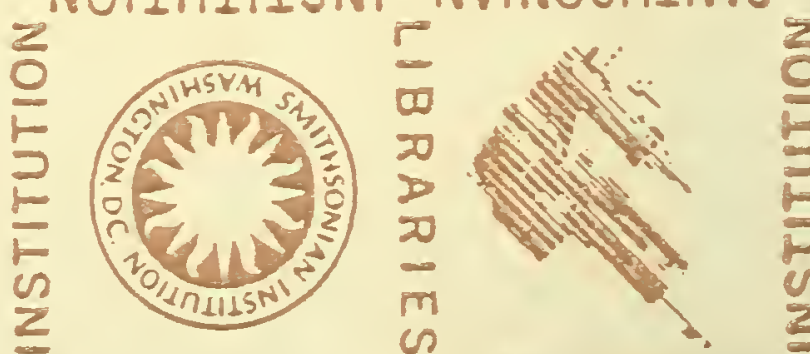

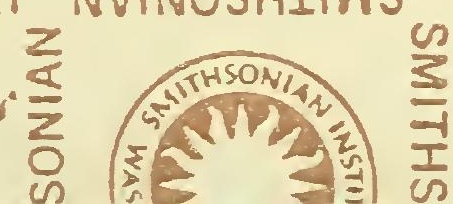

交

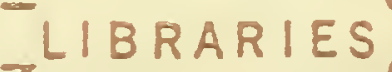

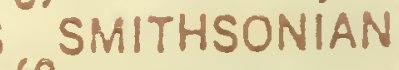





NK'

4210

R65R65

MHT

\section{ROBINEAU PORCELAINS.}

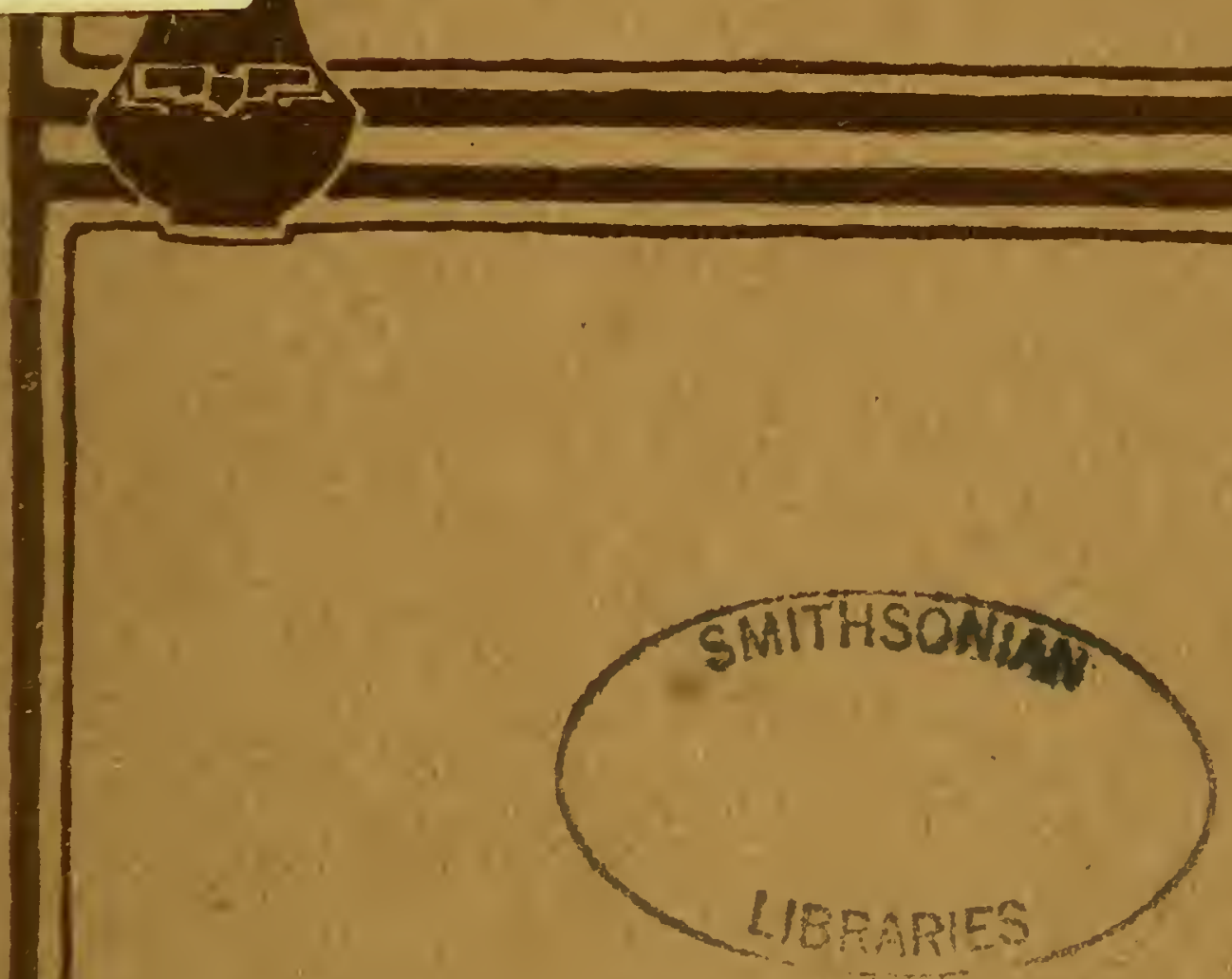






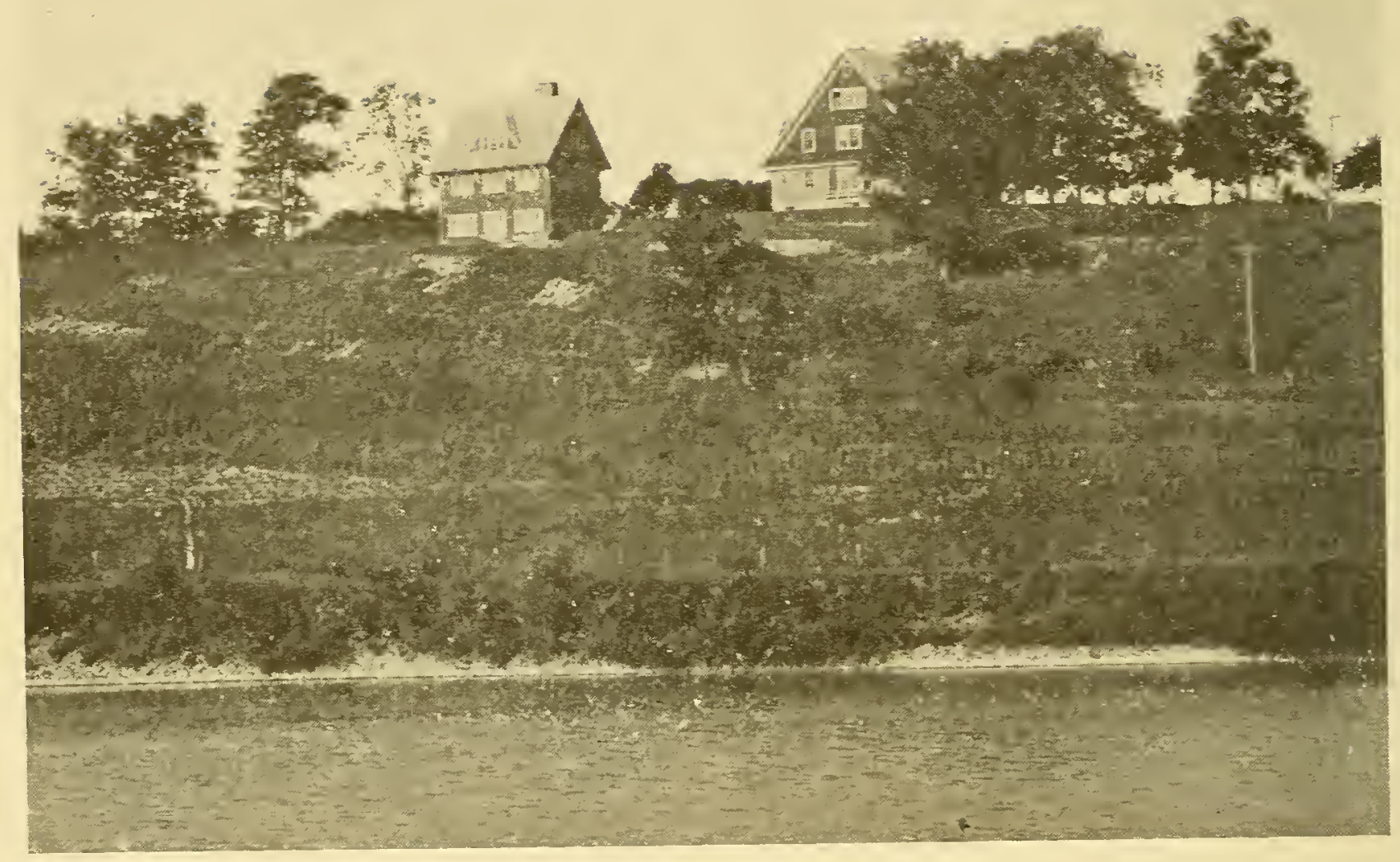

The Robineau Pottery. Mrs. Robineau's residence partly hidden by trees. 


\section{PORCELAINS FROM THE}

\section{ROBINEAU PO'T'TERY}

A delaide Alsop-Robineau, Potter

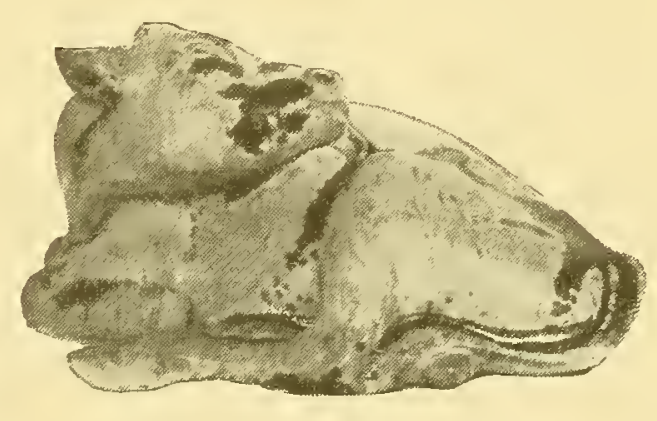

TIFFANY \& CO., AGEN'TS FIFTH AVENUE, NEW YORK CITY

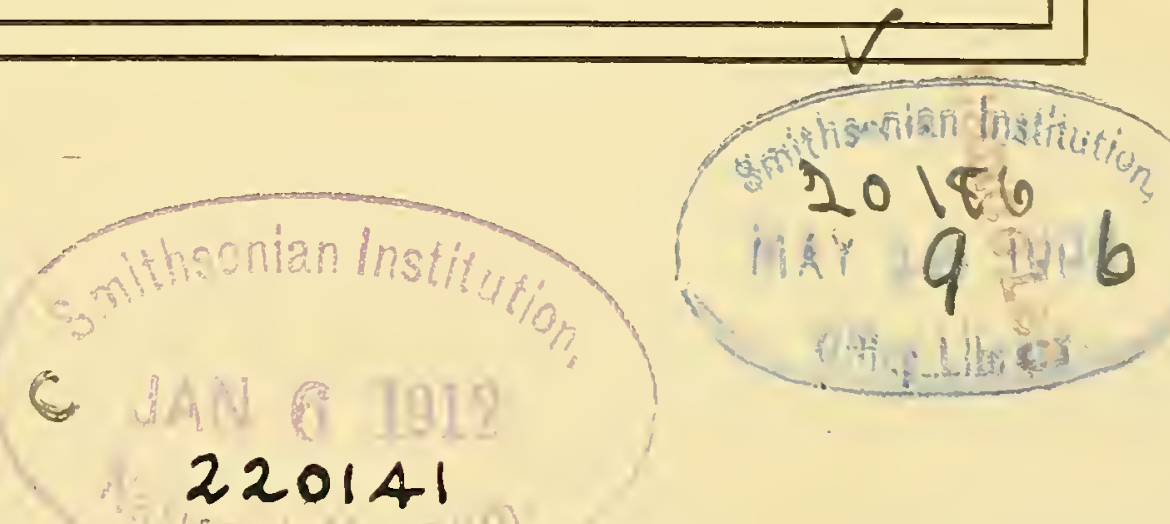




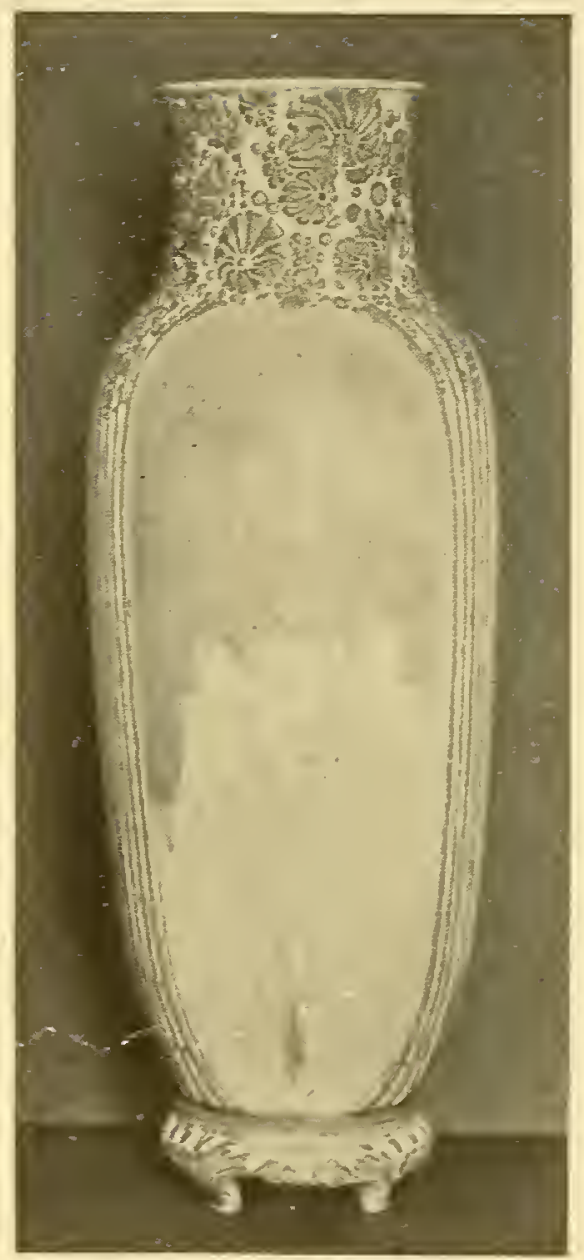

Vase, mat ivory glaze running into semi-bright glaze at base, chrysanthemum design in relief on white ground. 


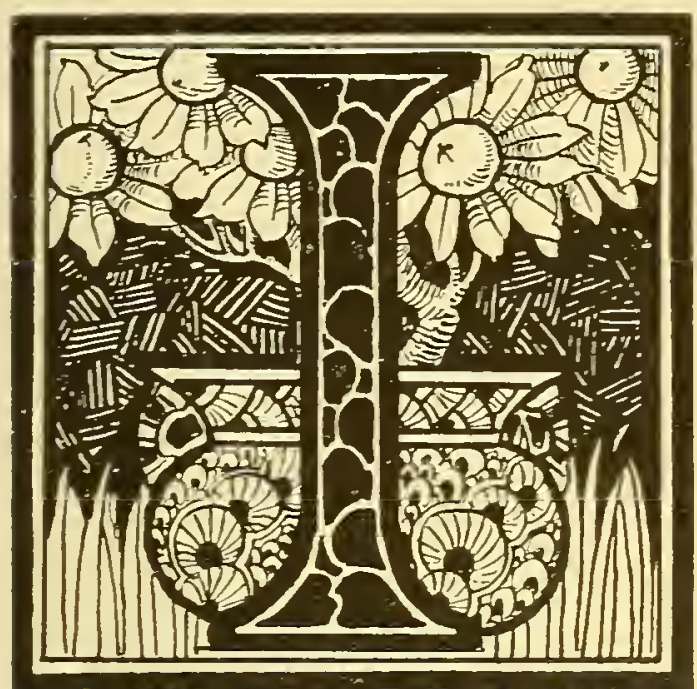

N recent years public taste in everything which constitutes household decoration has undergone an important change. The morement originated in France and was a natural reaction following a long period of decadence of all arts and crafts, for the XIX Century, a century of great commercial and industrial progress, was characterised by bad taste in art, absolute lack of simplicity, love of the gaudy and the gilded. In ceramics the most conspicuous style of decoration during that period was orerglaze painting of porcelain, a mistake from a technical standpoint, as overglaze colors, being low fired on the surface, are rapidly worn by age; a still worse mistake from an artistic standpoint, as this easy mode of decoration gave birth to the naturalistic school of design, the reproduction on china of flowers, fruit, landscapes, figures in natural colors, that is, painting instead of decorating pottery. The naturalistic china painter invariably considers a piece of pottery as a background for his painting, something which is of no interest in itself but will enable him to display his skill as a painter. and the more painting there may be on a rase, the better it will be in his judgment. The result of this complete ignor- 
ance of all the principles of design and decoration has been an absolute deterioration of shapes and a taste for overloaded ornamentation. And notwithstanding the healthy reaction which is so manifest in every branch of decorative art to-day, it is still much easier to sell at a high figure a rase of "hand painted" china than a piece of grand feu monochrome porcelain, notwithstanding the comparative ease with which hand painting is done, and the difficulties of obtaining a grand feu colored glaze of good quality.

In the United States the morement for the education of the public to a better understanding of what is tasteful and artistic in interior decoration has been greatly helped by the formation in all important centers of Guilds of Arts and Crafts. In all crafts to-day there is a healthy return to rules of simplicity in decoration, to the use of sober and restful colors, and a marked effort to improve forms, to remember that the shape as well as the decoration of an ornamental object, whatever its nature, pottery, metal or wood, should be appropriate to its use. It seems reasonable to hope that from such a movement will spring a decorative art which will not be the copy of foreign ideas, but truly American.

Howerer, there are in all reforms of this kind dangers against which the true artist must guard. Simplicity is an admirable rule, but simplicity is not necessarily crudity. There are among the potteries of the aboriginal Indians really artistic pots and jars of harmonious coloring and good shapes 


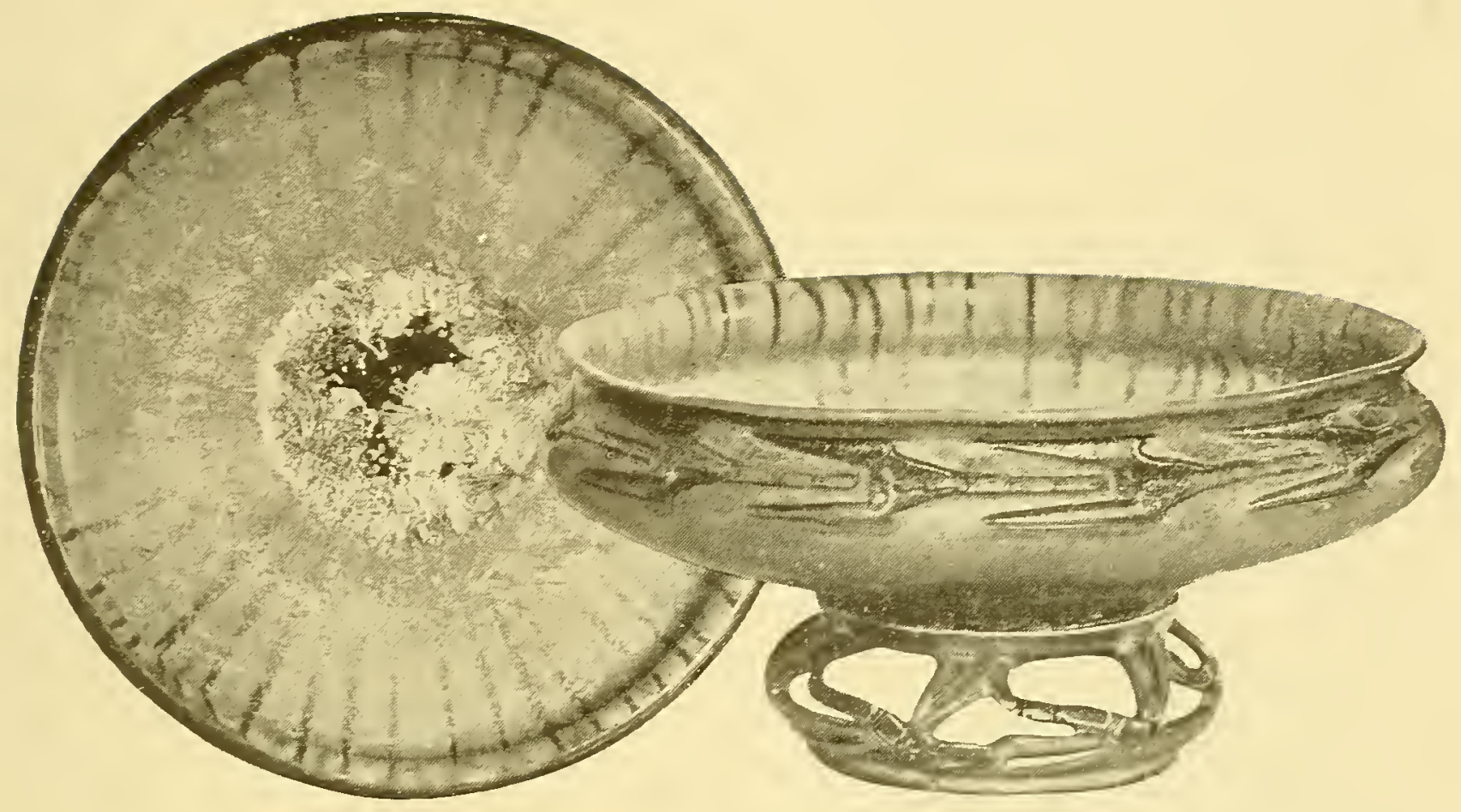

Bowl and Stand, dragon fly design, mat brown and green glazes outside, inside green crystalline glaze streaked with orange brown on edges. 


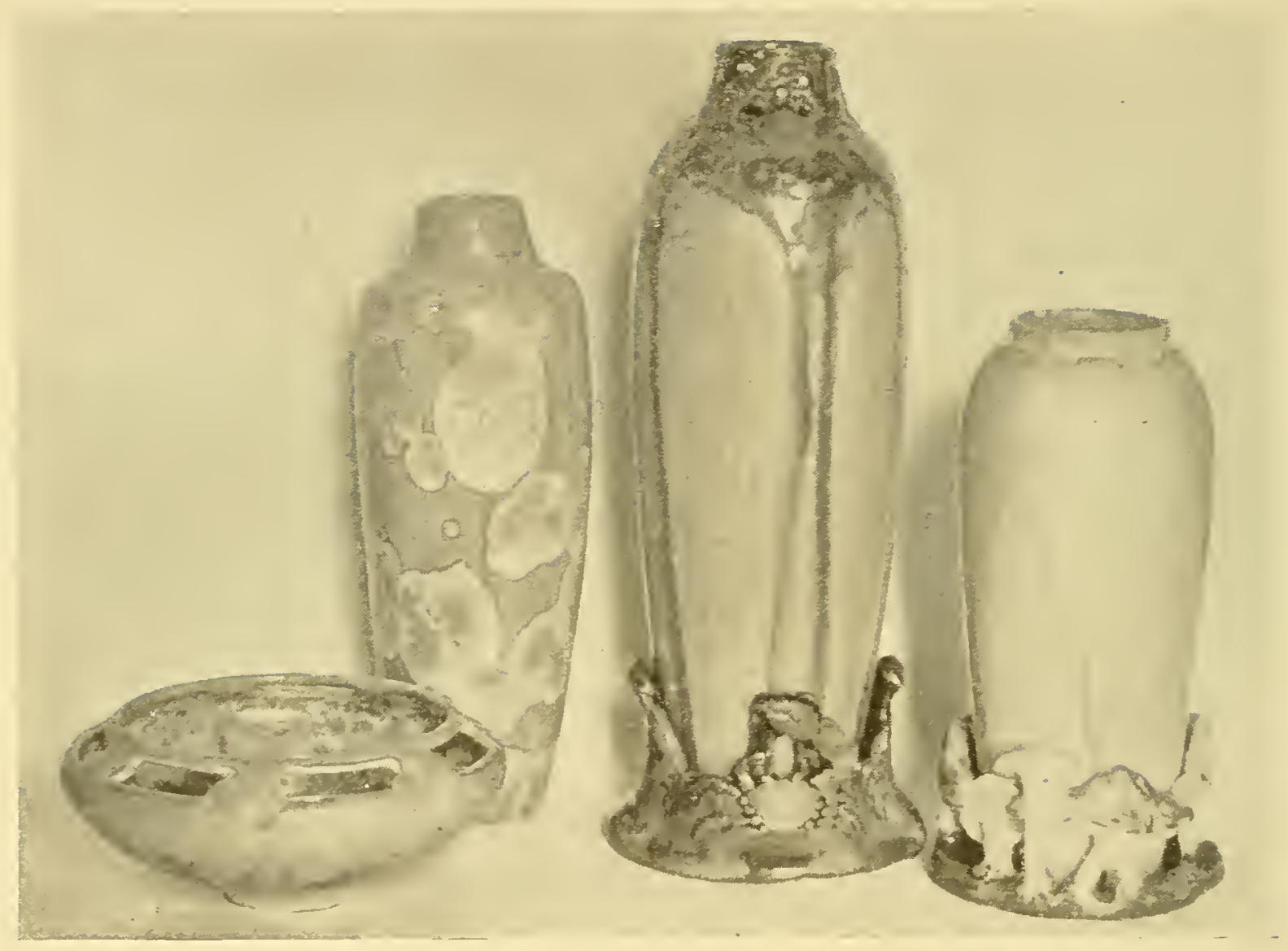

Group of Vases, crystalline and mat glazes of different colors. The vase on right side is a bright pink of copper glaze without crystals. 
crudely built by hand. This does not mean that all Indian potteries are good nor that it is sufficient to give by hand to a lump of clay a somewhat Indianesque shape, for it to be a work of art. This mistalie is made by many craftsmen today and the fad carried to such an extent that these extremists would not for a moment consider the possibility of making pottery in any other way than hand building. In all crafts the simplest effects often require much technical linowledge. The old Chinese vases are nothing but form and color but this simplicity is the expression of the most consummate skill in the potter's craft that the world has ever known.

Industrials have been prompt to notice the tendency toward taste and refinement in the selection of household furnishings, and art furniture, art metal work and art pottery are made on every side in a purely industrial and commercial way. This is good, as the object of every commercial undertaking is to produce as cheaply as possible, and thus furniture and ornamental objects, both substantial and artistically finished, are brought within the purse limits of people of moderate means who cannot indulge in the purchase of costly works of art. But factories, with the exception of special institutions like Sèvres, Berlin, Copenhagen, and one or two in this country, which keep staffs of trained artists, will not produce works of art. The independent craftsman should aroid the beaten path of these industrial establishments with which he cannot compete in price. His aim should be to do something better than can be done by 
factory work. In pottery for instance, since the charming mat green faiences of Grueby have come into rogue, the market has been flooded with mat green faiences of all linds, more or less artistic, generally less, and certainly of glazes inferior to the pleasant Crueby finish. The ceramic field is broad and the true artist should ain at producing something which will be his own individual work and not the copy and initation of something which has already been well done.

These were some of the reasons which decided Mrs. Robineau to try her hand at a line of work which has not ret been attempted in this country, porcelain decorative work at high temperature. Her first efforts have been well receired by artists and critics, and she hopes that with greater experience and a more complete mastery of this medium so difficult to handle, the liaolinic clay, her work will be more and more appreciated by the public at large.

Syracuse, N.Y., April, Igo6. 


\section{WHAT THE ROBINEAU PORCELAINS ARE}

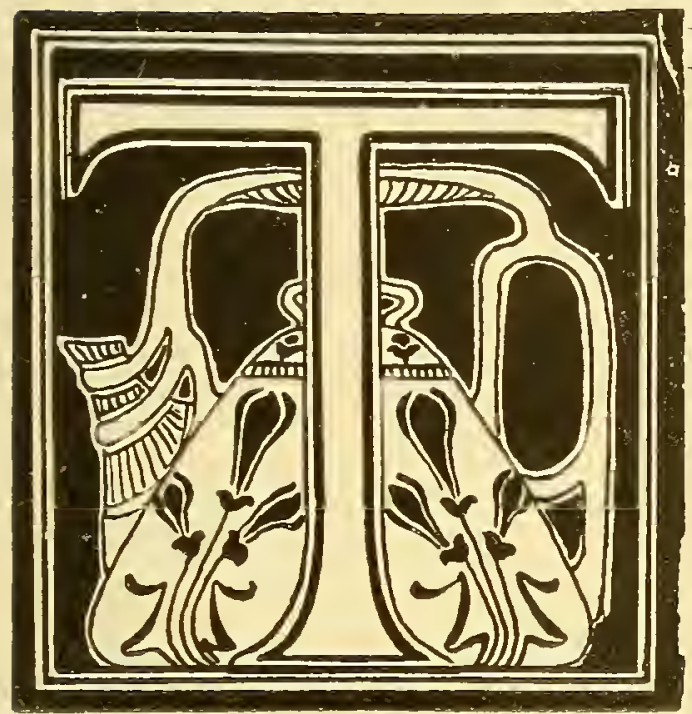

IIE Robineau Pottery is established on a beautiful hill on the outskirts of Syracuse, N. Y., and has a wide outlook over (Onondaga Lake and Valley. It is a studio rather than a pottery, as the ware is made entirely by Mrs. Robineau, from the wedging and throwing of the clay to the glazing, without any other help than that of her husband who has charge of the firing.

The casting process, which had been used at first for crystalline pieces, has lately been entirely discarded and hereafter the wheel only will be used. From an artistic standpoint a thrown piece is much more satisfactory in every respect than a cast piece. Throwing makes it possible for the artist not only to avoid the repetition of shapes but to constantly work for their improvement.

The body of the Robineau ware is a hard porcelain, made of native materials, very plastic and suitable to wheel work. The only glazes used so far have been mat or semimat and crystalline glazes. The decoration consists of modeling in the paste (carved and incised designs or pâte sur pâte reliefs), and inlaid glazes, as any underglaze painting would be impossible with the use of flowing glazes. 


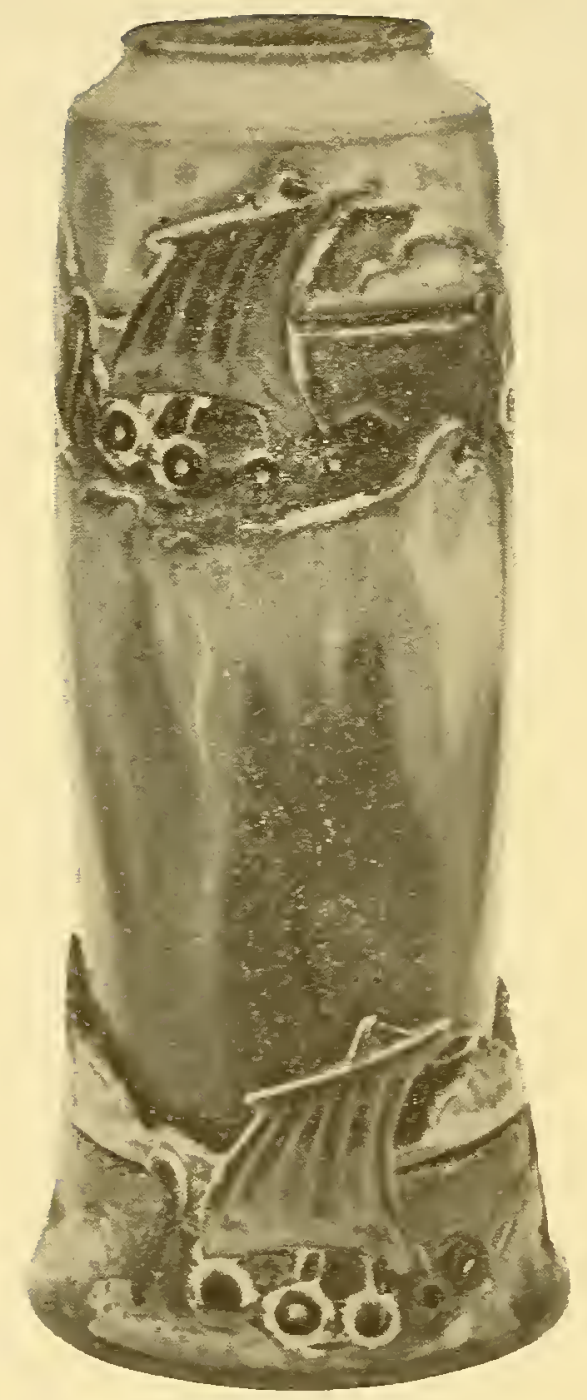

Vase, Vtking boat design, mat and semi-mat brown, green and blue glazes. 
Many pieces are simple shapes without other ornamentation than a beautiful glaze.

These porcelains are fired at Seger cones 9 to Io, or about 2400 degrees Fahrenheit, the glazes being developed at the same temperature. This is slightly higher than the point of firing of the present Sèvres porcelain. It is what the French call "grand feu" by opposition to the "petit feu" of ordinary clays or "demi grand feu" of soft porcelains.

Since Mrs. Robineau's porcelains have been shown to the public, although praise has been universal, many people have been surprised at the prices aslied. It is evident that very few people understand what the ware is and the difficulties of its malsing. Fine porcelains decorated with grand feu colored glazes have never been and will never be cheap. The art of producing these glazes is in its infancy aniong potters of the Western world, although it was practiced for many centuries in China, but the Chinese partly lost the art in the last two hundred years and it has been but recently revived. The best modern examples from the Sèvres or other European kilns bring very high figures and it is well known that the famous Chinese vases, for which collectors pay such fabulous prices to-day, were at all times ralued highly in China itself. II'siang, a Chinese writer who lived about 300 years ago, mentions a small saucer shape dish in red glaze which was valued at Iooo taels (about $\$_{1500}$ ) also a small wine pot of same glaze for which its owner had paid $\$ 3000$ in gold. The same writer even 
spealis of a celadon rase of the Sung dynasty, for which a collector, General Huang, had paid I50,000 taels, a price which would stagger the most liberal collectors of the present day. These of course were exceptional prices for exceptional specimens and it is doubtful if the rarest and finest of these Chinese glazes will ever be equalled by modern potters. Modern processes are different. Potters of the present day will derelop and have already developed glazes which were entirely unknown to the Chinese, like the mat glazes or the crystallizations of zinc oxide, besides duplicating some of the old Chinese effects. They may not revive the old art in all its masterly perfection, but the fact remains that all grand feu colored glazes are difficult to control and costly to produce, and as this point is not clearly understood by the public at large, a few words of explanation will undoubtedly be welcome to buyers of modern handicraft. Let it first be understood that there is no secret about the making of true porcelain. Mrs. Robineau's first experiments were made after the publication of a treatise by M. Taxile Doat of Sèrres, in which the Sèrres formulæ for porcelain paste and glazes are given, with the most minute directions for the making of the ware. This treatise was first published in the form of articles in Keramic Studio, the monthly Magazine of which Mrs. Robineau is editor, and it is now for sale in book form.*

*Grand Feu Ceramics, by Taxile Doat, of Sèrres, translated from the French by S. Robineau. For sale by Keramic Studio Pub. Co., Syracuse, N. Y. Price $\$ \mathbf{T} .50$ postpaid. 


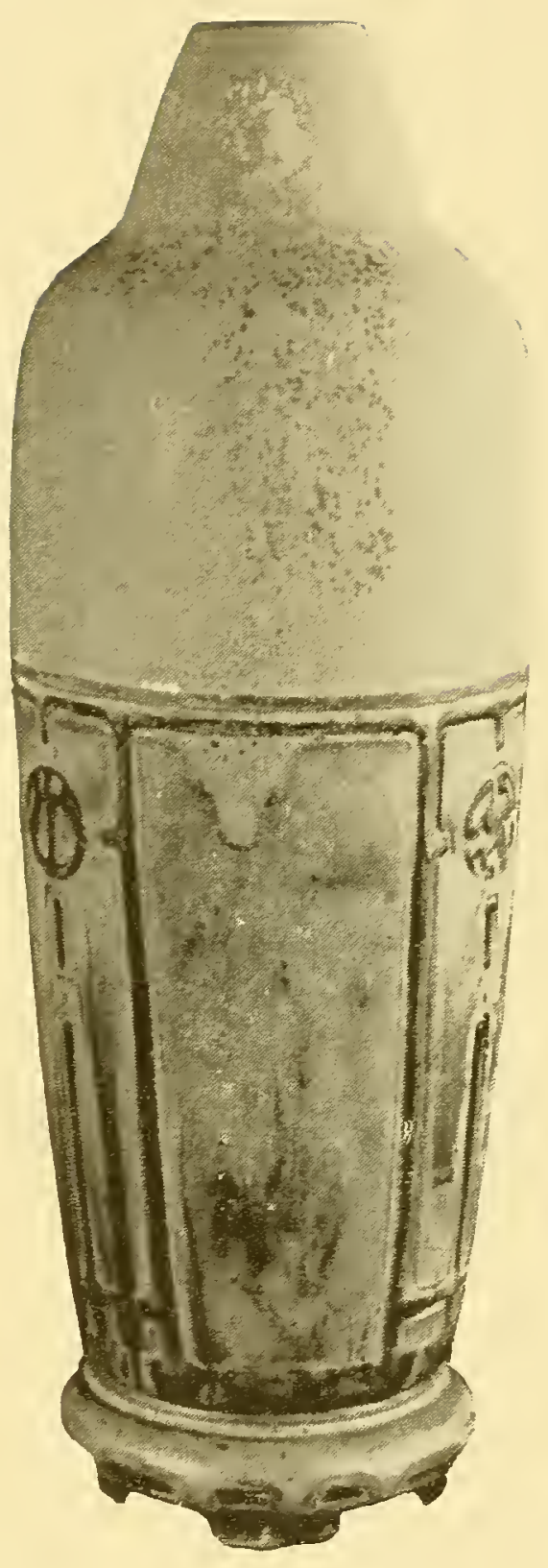

Large Vase and Stand, mat brown glazes of different shades and very fine texture. 


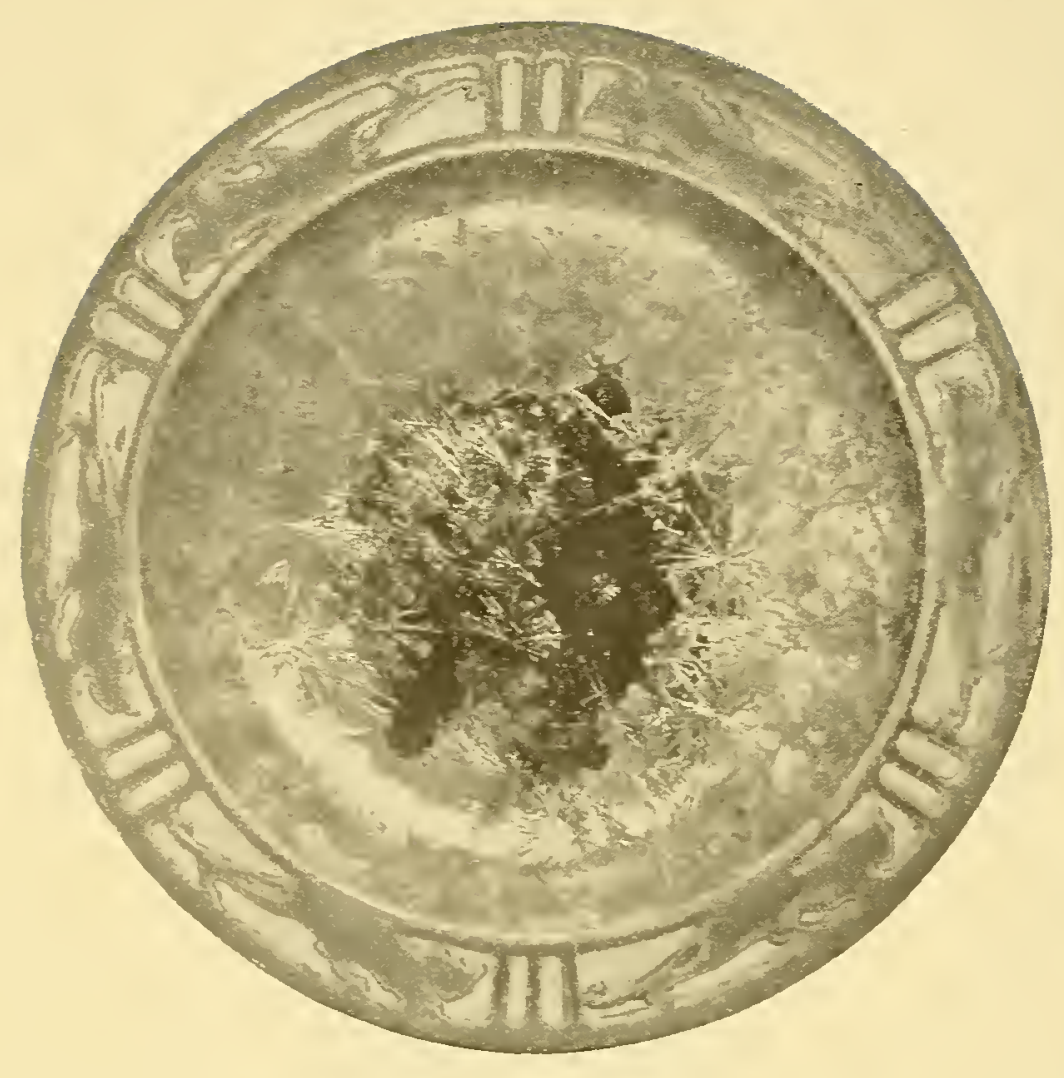

Coupe, cat design on mat ivory ground, underside mat light brown, inside rich lemon yellow crystalline glaze. 
It is neither advisable nor possible to follow exactly the instructions given in M. Doat's book, as they apply to French materials, and clays obtainable in this country will be found somewhat different. But every artist potter has the opportunity of doing what Mrs. Robineau did, take the I)oat treatise as a foundation for grand feu work, develop a body and glazes which will suit his work, give to his productions individuality and originality; and make them different from anything else. The field is unlimited and hardly explored yet. It is the true field for the artist, because such a ware cannot be successfully made on the factory plan. It requires the most careful and delicate handling from beginning to end, it needs the touch of the artist in all phases of the production, from the throwing to the glazing. Individual potters who attempt to make cheap pottery by using low fired clays, find themselves in competition with the many factories which produce wares of this kind and sometimes quite artistic wares, and can sell them at low prices by producing them in large quantities. In grand feu work this competition is not to be feared. But artists should remember two things: It is the most difficult and costly ware to make, and it should not be undertaken with the primary riew of maling money. In ceramics the only profitable production, from a financial standpoint, is that of cheap wares made on the factory plan. Grand feu work should be undertaken with the view of producing something beautiful, durable and unusual. The work is fascinating and the sat- 
isfaction of making a ware with qualities of color and texture which no ordinary clay could give, and which will remain forever as it comes out of the kiln, should be compensation for the hard work it requires.

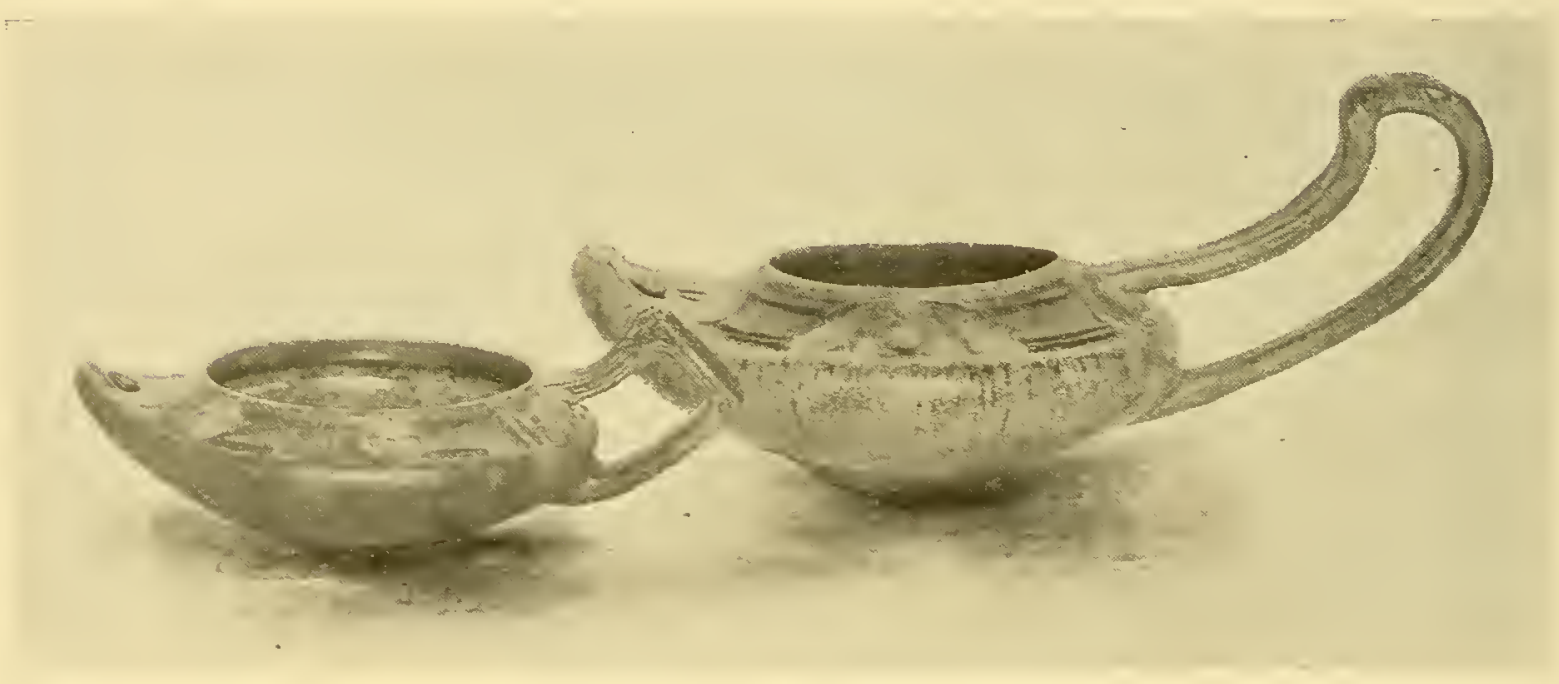

Violet holders in shape of antique lamps, conventional designs, the larger one in mat green glaze speckled with black, the smaller one in mat black glaze. 


\section{HARD PORCELAIN}

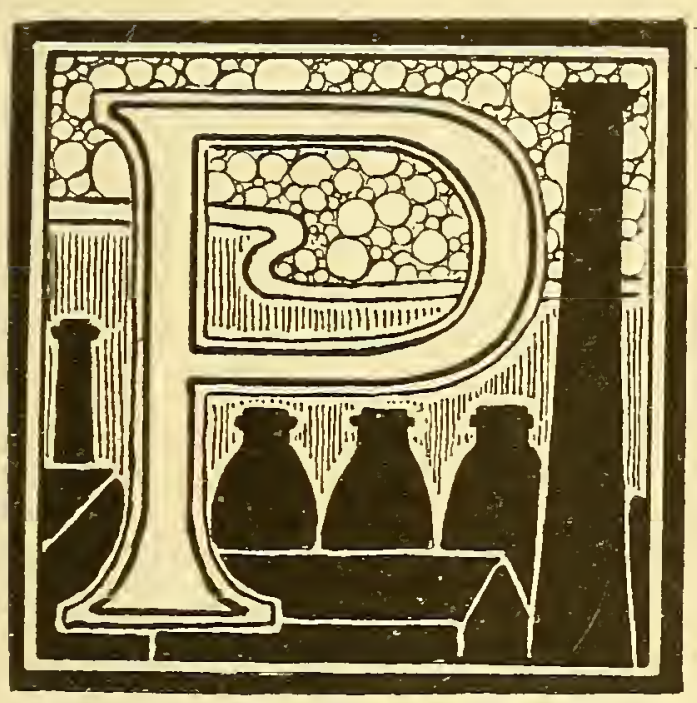

ROF. Chas. F. Binns, in the Clay Worker for January r906, says: "The term 'porcelain' has often been misapplied, for instance in the expressions soft porcelain, semi-porcelain, opaque porcelain and the like. Strictly the name should be confined to hard porcelain made after the Chinese manner, body and glaze being fired together at high temperature. China wares, such as hotel china, Belleek and English bone china are not porcelains eren though they are translucent. They receive the hard fire in the biscuit state only and the glaze is added at a subsequent and less serere burn." Accepting this definition as correct, there has been so far only one true hard porcelain made in this country and fired at the temperature used by the Chinese. This is the porcelain made by Mrs. Robineau. A true porcelain is made of a mixture of kaolin, feldspar and quartz, nothing else. These three elements can be mixed in different proportions and the resulting paste will be more or less hard, that is, will vitrify at a more or less high temperature. The higher the temperature, the purer and finer the body. A typical example of porcelain made and decorated at an extremely high fire is the beautiful Copen- 
hagen ware, with its great purity of paste and the refined quality of its decoration. Here the decoration is used only to bring out the beauty of the body. It consists in designs painted with colored ships under the glaze; the glaze is fixed and translucent and covers the design without disturbing it, and this use of a fixed glaze has the great advantage of reducing the loss in firing to a minimum, and consequently cheapening the cost of manufacture. Such a ware can be made on the factory plan, although it requires clever artists to do the modeling and underglaze painting. But a disadvantage of the high temperature reached is that the range of colors is rery limited, only a few colors, and a few shades of these colors, the blues, greys, greens and pinks, resisting the intensity of the fire.

Another process which is used now at Sèrres, Berlin and by indiridual potters in Europe, which was also used in the production of the old Chinese monochrome rases, and has been adopted by Mrs. Robineau, consists in decorating the ware with colored glazes. The coloring oxides are thoroughly incorporated into the glaze and the latter is fired at the same temperature as the body. In order to keep a wide range of colors, it is necessary to develop a body which will fire at as low a temperature as hard porcelain can be made, about 2400 degrees Fahrenheit.

From an artistic standpoint it is a mistake to further reduce the point of vitrification of the body by the introduction of fluxing elements, such as bone. The bone or 

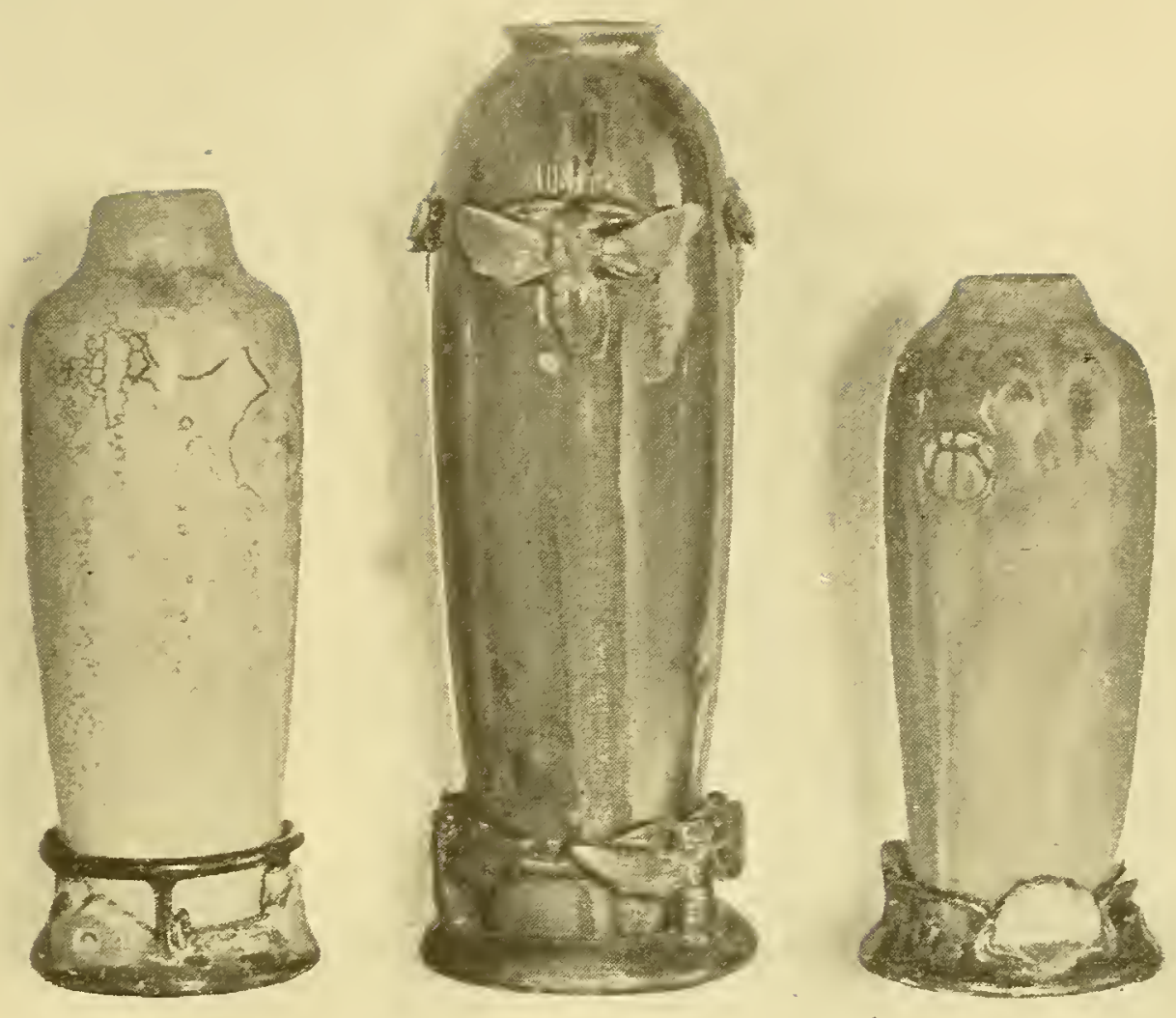

Vases with Carved Stands. Vase on left side, grey green crystals on salmon ground. Center vase, bee design, brown glaze with green crystals. Vase on right side, brighl pink of copper glaze. 
soft porcelain of the English and American manufacturers has great commercial adrantages. By maling possible a comparatirely low fire, it cheapens the cost of manufacture enormously, but on these artifical porcelains the colors will never have the refined and rare quality which "grand feu" alone can give. Howerer interesting, the Doulton red, which is a low fire enamel, does not compare with the Chinese sang de boeuf or the flammé reds of Sèrres and Hariland. Notwithstanding the excellence of technique, the pâtes sur pâtes of Solon on the soft Minton porcelain have not the fine quality of the pâtes sur pâtes of Taxile Doat on the hard Sèrres ware. The French have always realized this and have strictIy adhered to hard porcelain, even for their commercial table ware.

Another body than porcelain can be used for grand feu work, in many cases to great advantage. It is the stoneware which the French call "grès". It is a vitrified body like porcelain but differs from it by being neither white nor transhucent. It has been used by the Chinese for many of their monochrome vases. It is cheaper and easier to handle than porcelain paste, and grand feu colors of good quality can be dereloped on it. Howerer colored glazes on porcelain have a delicacy, freshness and brilliancy which they do not acquire on grès. 


\section{COLORED GLAZES}

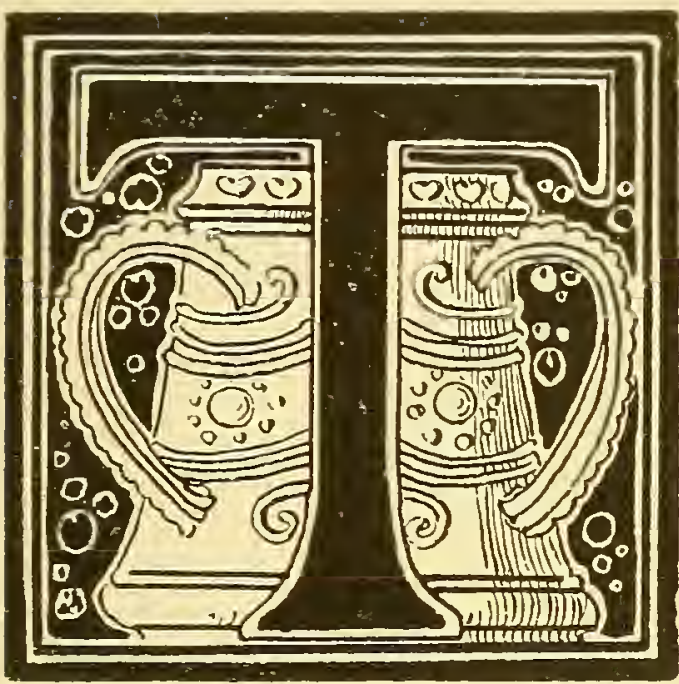

HE development of colored glazes at high temperatures constitutes a complete revolution in the processes of decoration of modern porcelain. This revolution is the result of important discoveries made in the last twenty-five years by European chemists, especially Seger in Germany and the Sèrres chemists in France, and it was brought about by the introduction into Europe during the latter part of the XIX Century of the marvelous porcelains from China. These master pieces of the potter's art with their extraordinary glazes, sang de boeuf, peach blow, celadon, turquoise blue, clair de lune, etc., and the wide range of colors evidently obtained in a high fire, were a revelation to European potters, who had long ago solved the problem. of porcelain making, but were practically confined for the decoration of their ware to the easy process of overglaze painting. Colored glazes are flowing, not fixed. They must be applied in successive heavy coats and will develop their brilliant tones only when flowing over the vase at a high point of firing. They flow not only over the vase, but orer its supporting column and bat, and vase, column and bat are often found at the opening of the kiln to form a solid mass, 


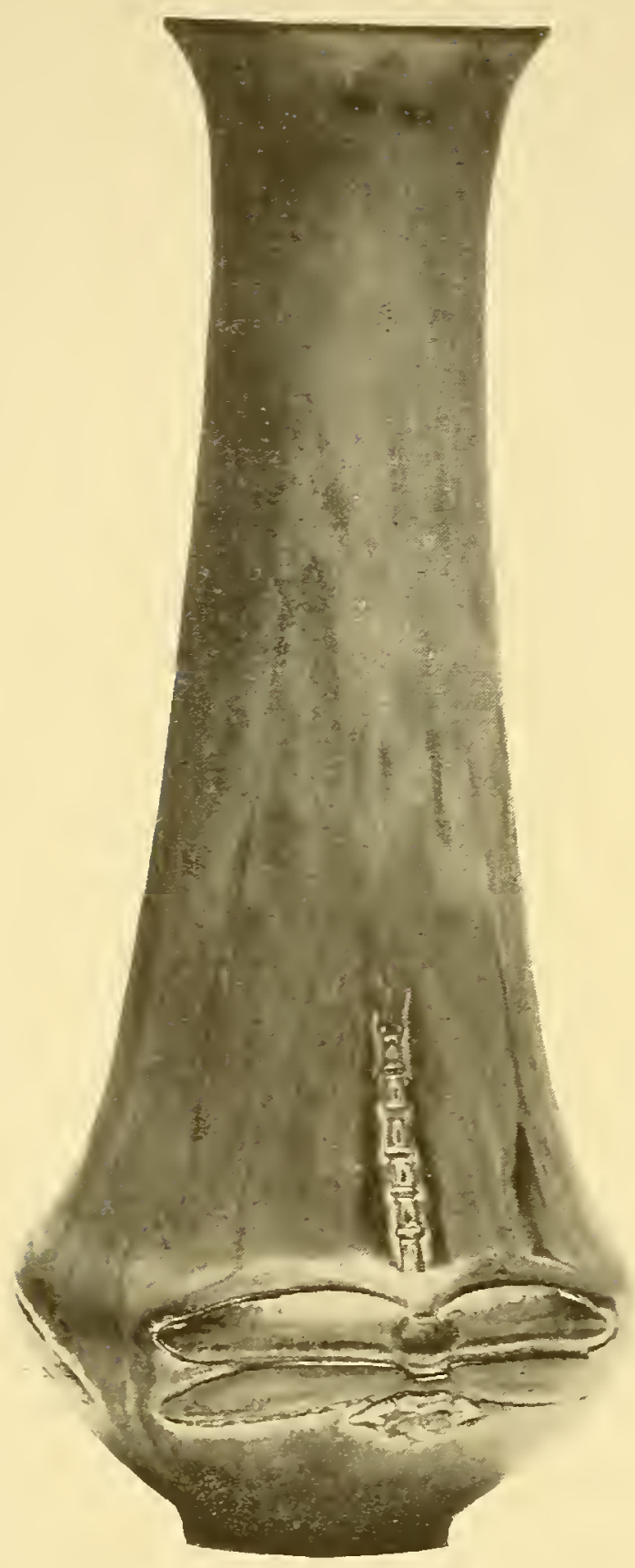

Large Vase, dragon fly design, mat brown and green glazes. 
and must be carefully ground apart. There are on this account rery great difficulties and losses in the placing and firing of the ware, especially in the firing which cannot be done with coal, as coal injures the colors, and these difficulties are increased by the fact that colored glazes are extremeIy sensitive to the condition of the kiln atmosphere. Some will derelop only in a strictly oxidizing atmosphere, others require a reducing or smoky fire. The slightest nistake in the handling of the firing may ruin a rase. At Sèrres, notwithstanding the minute care in the preparation of body and glazes, and the use of experienced firers, the loss in the firing of these glazes is on the arerage $30 \%$, and there are eren among good pieces great differences in the quality and texture of the glaze. For instance the fer choice rases with crrstalline glazes which were exhibited at St. Louis by the Sèrres factory, had been selected out of 300 to 400 pieces, and most of them had been fired tro or three times and only in certain parts of the kiln where it was known that fine crystals could easily be obtained. Such a ware cannot be produced at low prices, and the choice and rare pieces which occasionalIy come out of the kiln must make up for spoiled and lost pieces. But the rery difficulties and uncertainties of the work have a fascination for the true artist potter. Disappointments and failures are soon forgotten in the effort to tre again and succeed.

Mrs. Robineau has been rery successful with crystallizations. Crystalline rases, with their endless variety of beauti- 
ful colors, should appeal to collectors of fine wares, who should be careful to select choice specimens not only in color but in texture of crystals. To be perfect, crystallizations should be smooth and glossy. Rough spots should be avoided, although they are most difficult to aroid and will be found on examples from the best European factories. A carefully selected collection of these charming glazes will undoubtedly grow in value in the years to come.

Howerer interested in crystalline glazes with their broad range of colors, their brilliant and often unexpected effects, Mrs. Robineau prides herself more in her carved and modeled rases decorated with mat and semi-mat glazes, of those restful and refined tones which are due to the high firing and the high quality of the paste. Nany pieces are reproduced here but unfortunately half tone reproductions can give no idea of the rich coloring. The glazes which Mrs. Robineau has thus most successfully used are a mat brown of different shades, from the mat cream or irory to the mat dark brown, a dark and a light green, a mat dark blue which is very difficult to control, sometimes coming out brilliant instead of mat or streaked with flashes of bright glaze, a pale blue of good quality which on occasional pieces comes a bright glaze with purplish flashes resembling the clair de lune blue of the Chinese, a mat orange red, a mat creany white, and a mat black which has been found very satisfactory in the making of stands for rases.

A combination of mat and crystalline glazes has been 

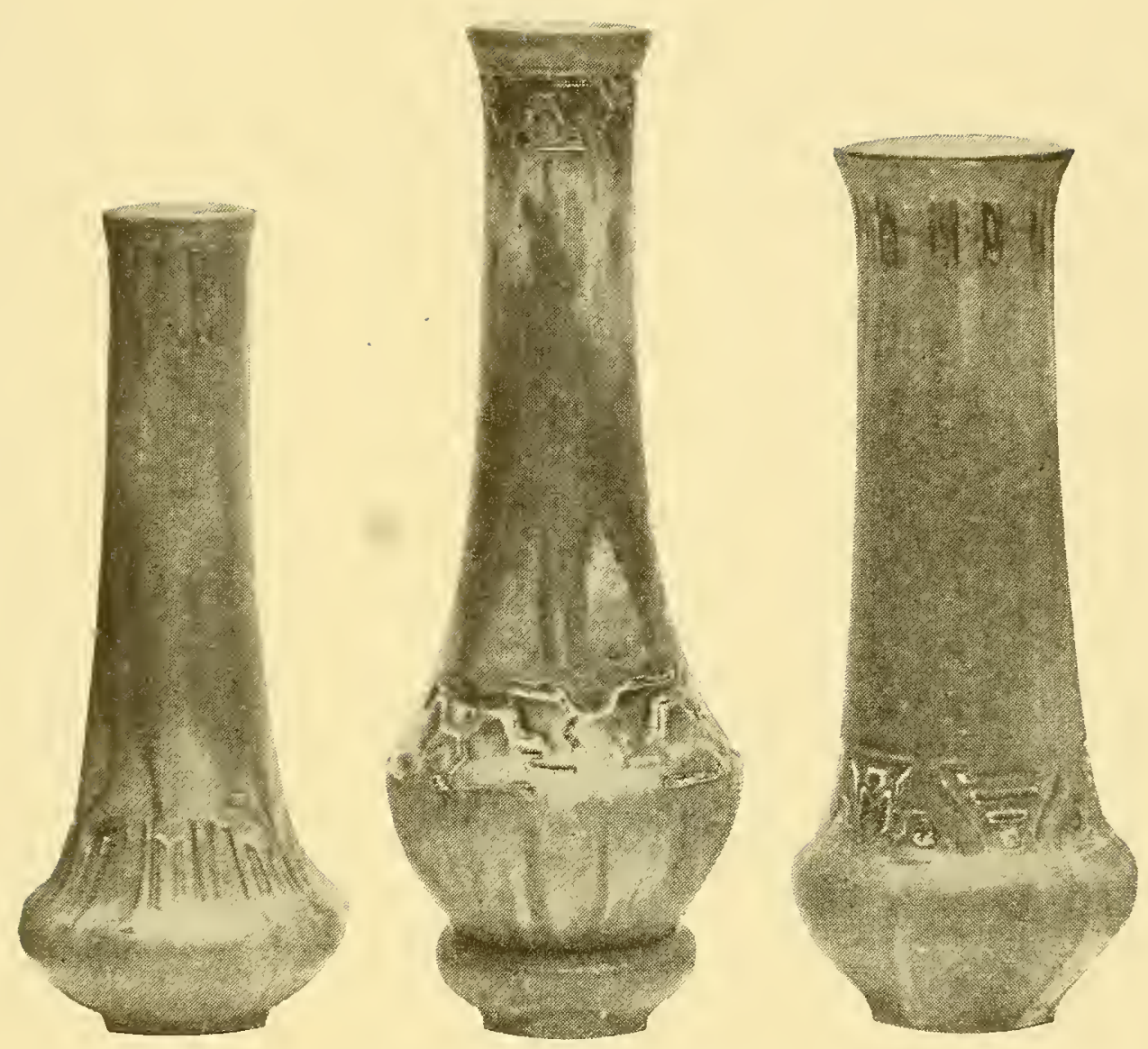

Small Vases, Indianesque coloring and designs. Mat glazes in brown, black, green, blue, reddish orange and cream. 


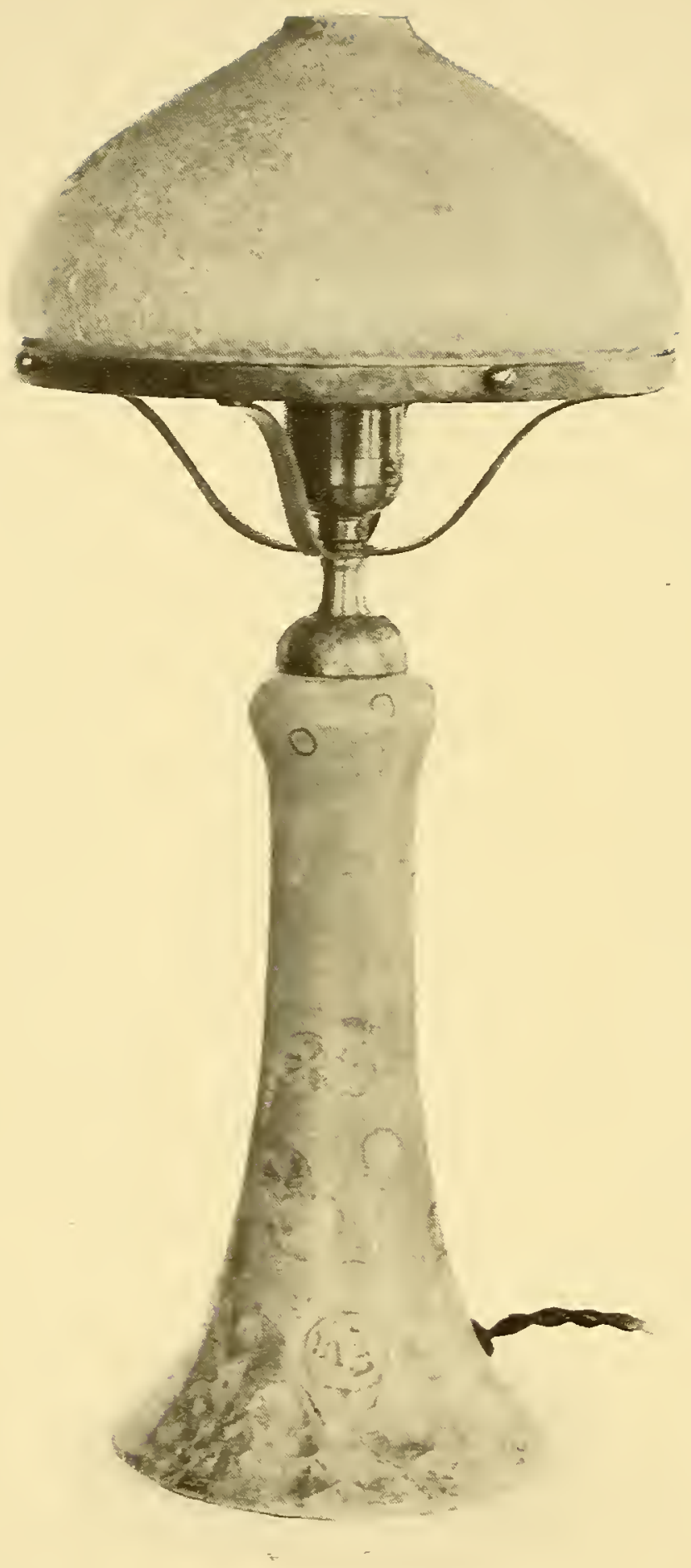

Electrolier and shade in pale green crystalline glaze. 
happily used in the decoration of bowls and coupes, the mat glazes being outside and crystals inside.

Although bright glazes have not been used outside of crystalline glazes, two glazes, which are modifications of crystalline glazes, have been accidentally developed and have proved to be of very fine quality but exceedingly difficult to control and absolutely perfect only on occasional pieces. One is a very delicate pinli, the other an opalescent sea green. Both are copper glazes, and a pinls of copper is especially interesting, as modern potters as a rule obtain their pink from tin. One or two unusual specimens on which Mrs. Robineau used her copper glaze show flashes of the three characteristic colors of copper: red (in pints shade), green and turquoise blue.

Mrs. Robineau is constantly experimenting on new glazes, and is now making promising experiments on flammé reds of copper. 


\section{MARKS}

The following marks have been used on Robineau porcelains:
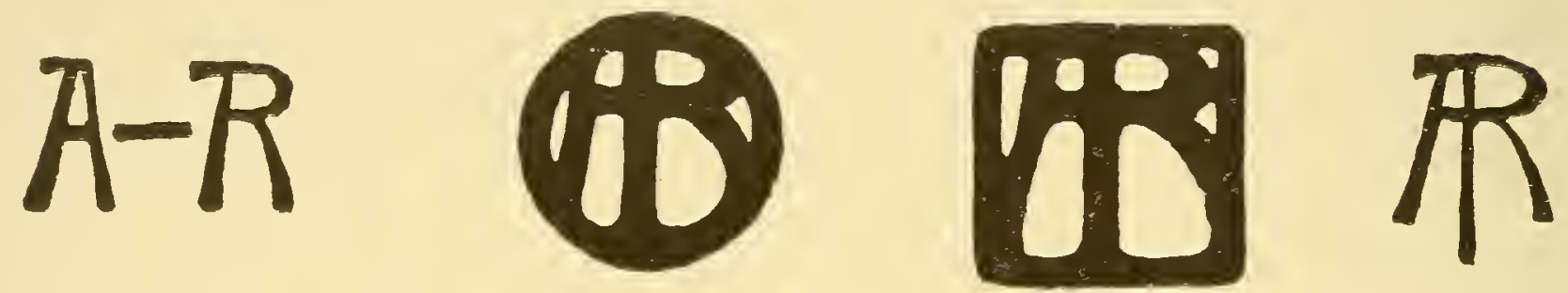

The first mark used was the initials $A$ and $R$ separated by a hyphen; this was used in the early experimental stage, mostly on cast pieces.

The present mark is a combination of the initial letters of Mrs. Robineau's name, in either a square or a circle, and is found on pieces thrown on the wheel and entirely made by her.

The mark R. P. is found only on cast pieces 60 and stands for the initial letters of Robineau Porcelains. As casting has lately been discontinued, this mark will probably be little used hereafter. In one or two of the first moulds for casting a mark made of four trees in a square was impressed in the mould, but as it did not come out distinctly, it was soon abandoned. A few pieces only hare been sent out without marls. 


\section{PRICES AND ORDERS}

Prices of a Robineau rase vary very much according to quality, the artistic success of the rase and perfection of glaze determining its value much more than the size. Although good pieces can be obtained for less, really fine pieces of crystalline glazes cost from $\$_{15}$ to $\$ 25$, and of mat glazes with incised or carved decoration $\$ 20$ to $\$ 50$. Nore is asked for unusually fine specimens.

Mrs. Robineau will receive orders but cannot promise to execute them in a short time, as she is obliged to fire only at long intervals, and many pieces will require two or three firings. Quite often a piece thus made on order will fail, and will have to be made again, perhaps sereral times.

\section{\%}

The illustrations are all of pieces thrown on the wheel and entirely made by Mrs. Robineau, with the exception of the calf on itle page which is cast from a model by Fred Roth, sculptor. 
"The Robineau Pottery is original and unique. It carries itself as if conscious of artistic taste and refined quality. It is, in a word, precious, and a fit companion of choice silver, rich draperies and dainty books."

$$
\text { Prof. Chas. Binns, in "The Craftsman." }
$$

๑

"The examples of texture glazes, of transmutation and opalescent glazes are excellent, while the display of crystalline glazes is most remarkable, and one that would be a credit to any factory in the world.".

$$
\begin{aligned}
& \text { A. V. Rose, of Tiffany \& Co.. } \\
& \text { In "American Pottery Gazette." } \\
& \text { ( }
\end{aligned}
$$

"I have seldom seen finer crystals than those shown in your photographs."

Taxile Doat, of the Manufactory of Sevres, France. ๑

"This charming American porcelain ware seems destined to bring American pottery a world's renown." "International Studio."

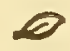

"Taxile Doat has shown me photographs of your crystallizations which I think are superb."

E. Difloth, La Louviere, Belgium. 




OILIIISNI NVINOSHLIWS SJIYVYGITLIBRARIES SMITHSONIAN INSTITU
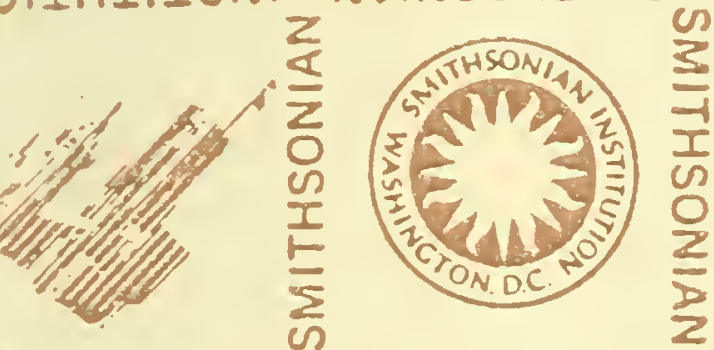

BRARIES SMITHSONIAN THSONI U

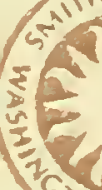

$\sin _{\text {ON.DC }}$

OIITIILSNI
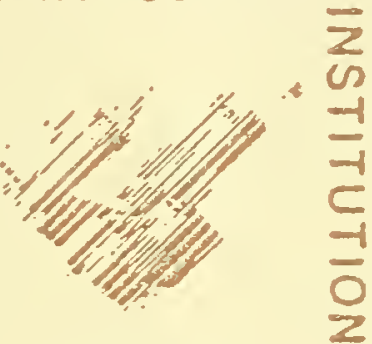

NYINOSHLIWS

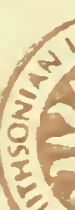

25
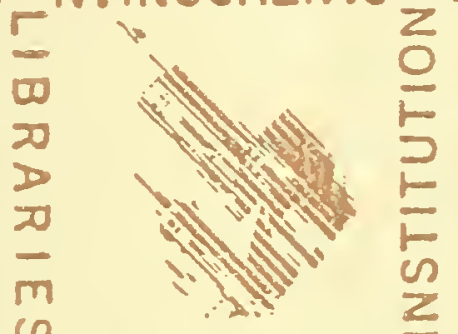

en

SMITHSONIAN
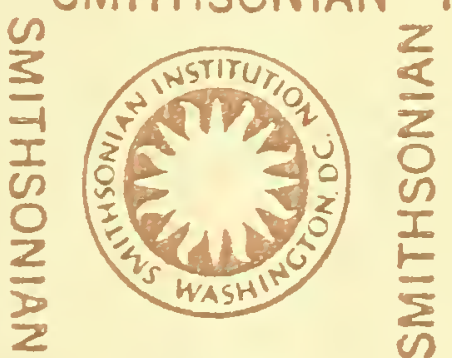

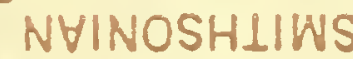
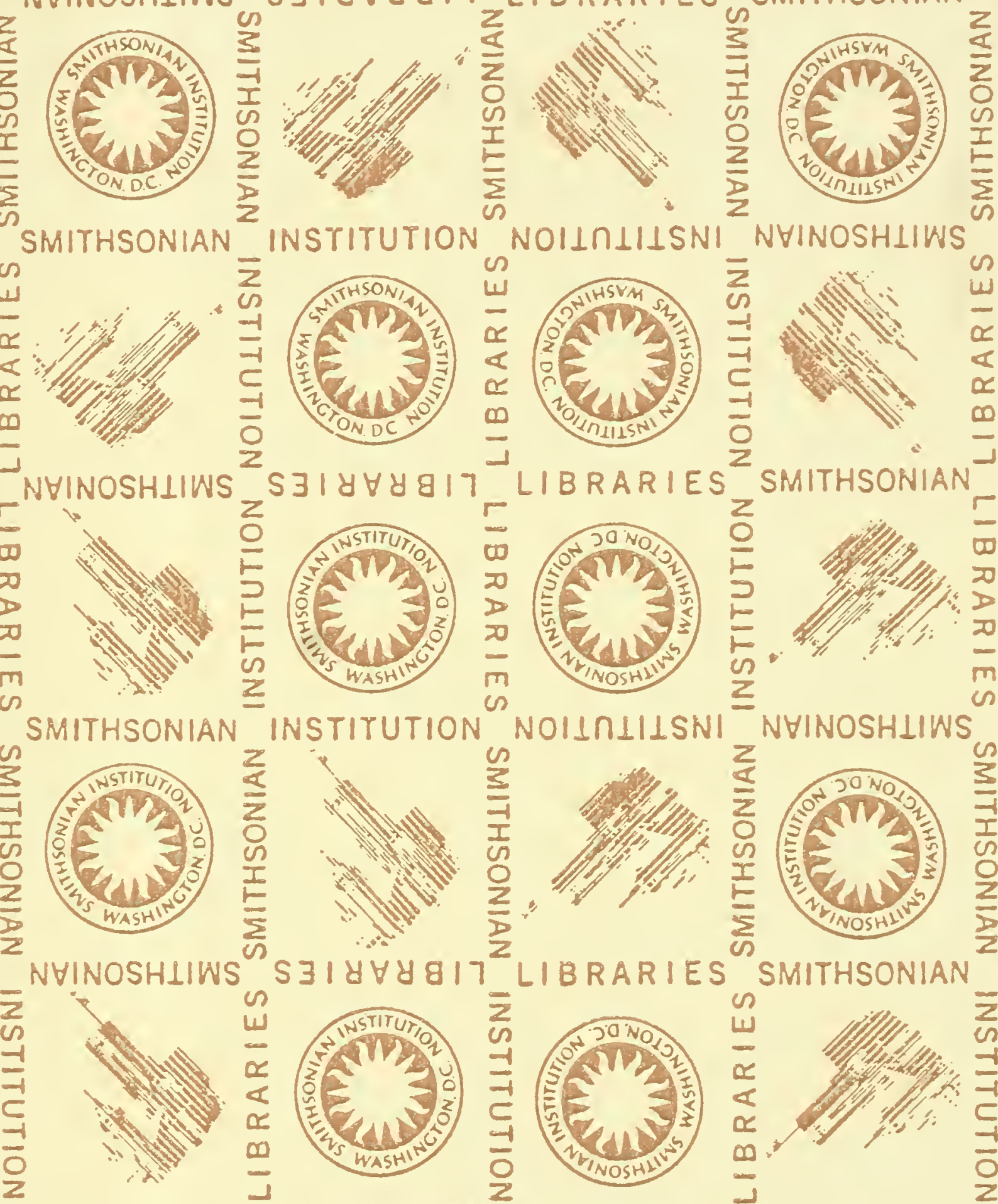

NOILIILSNI
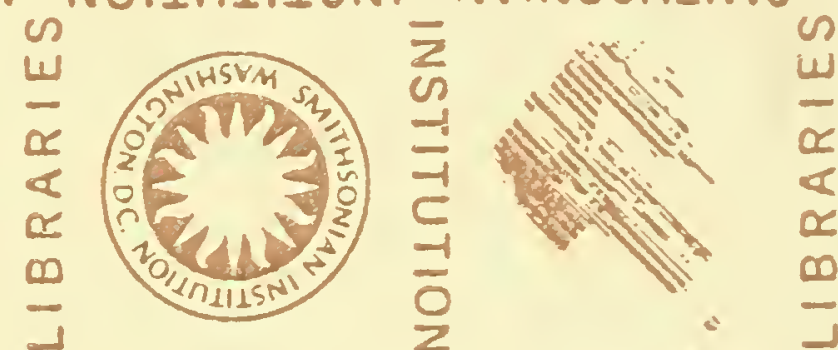

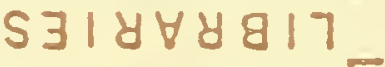
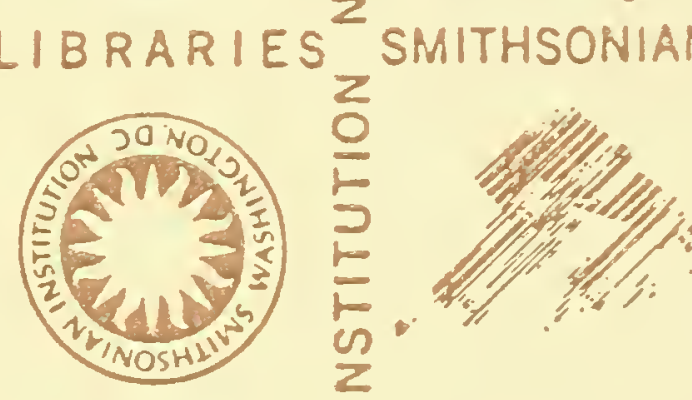

$\infty$

INSTITUTION
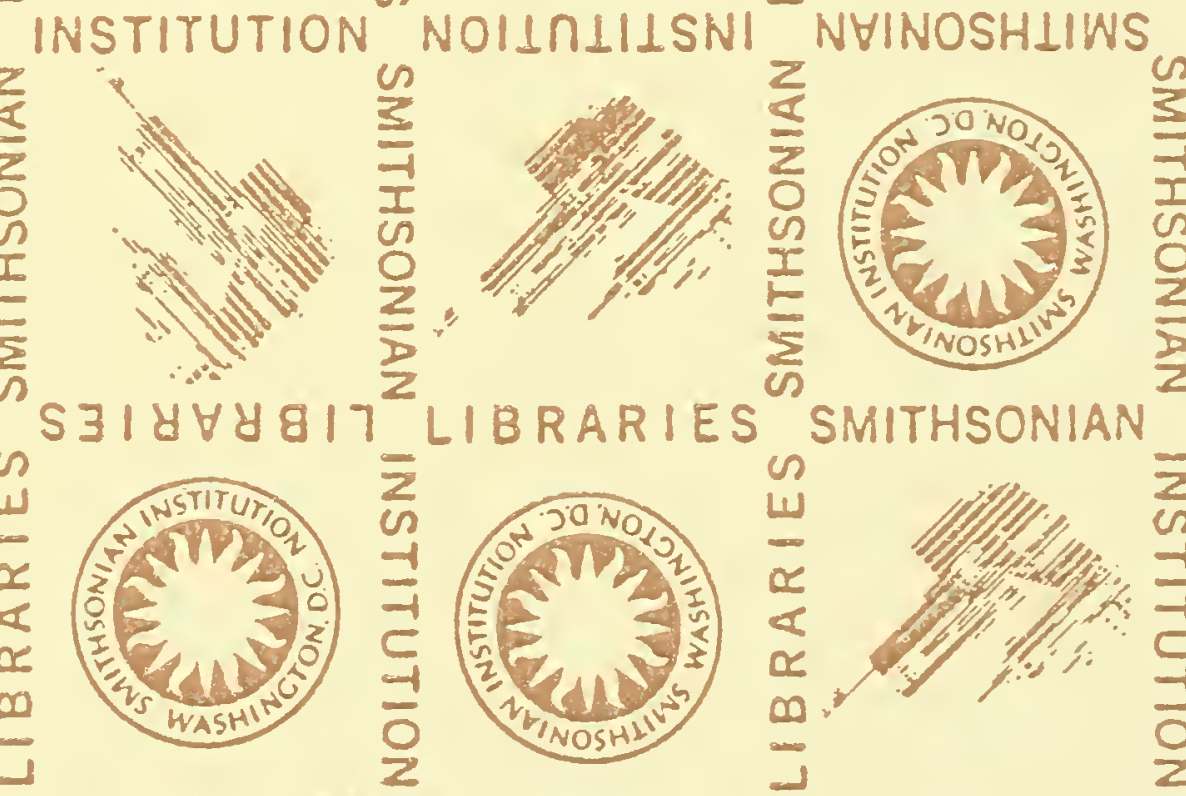

$\frac{1}{1}$
$\frac{1}{c}$
$\frac{1}{0}$
2
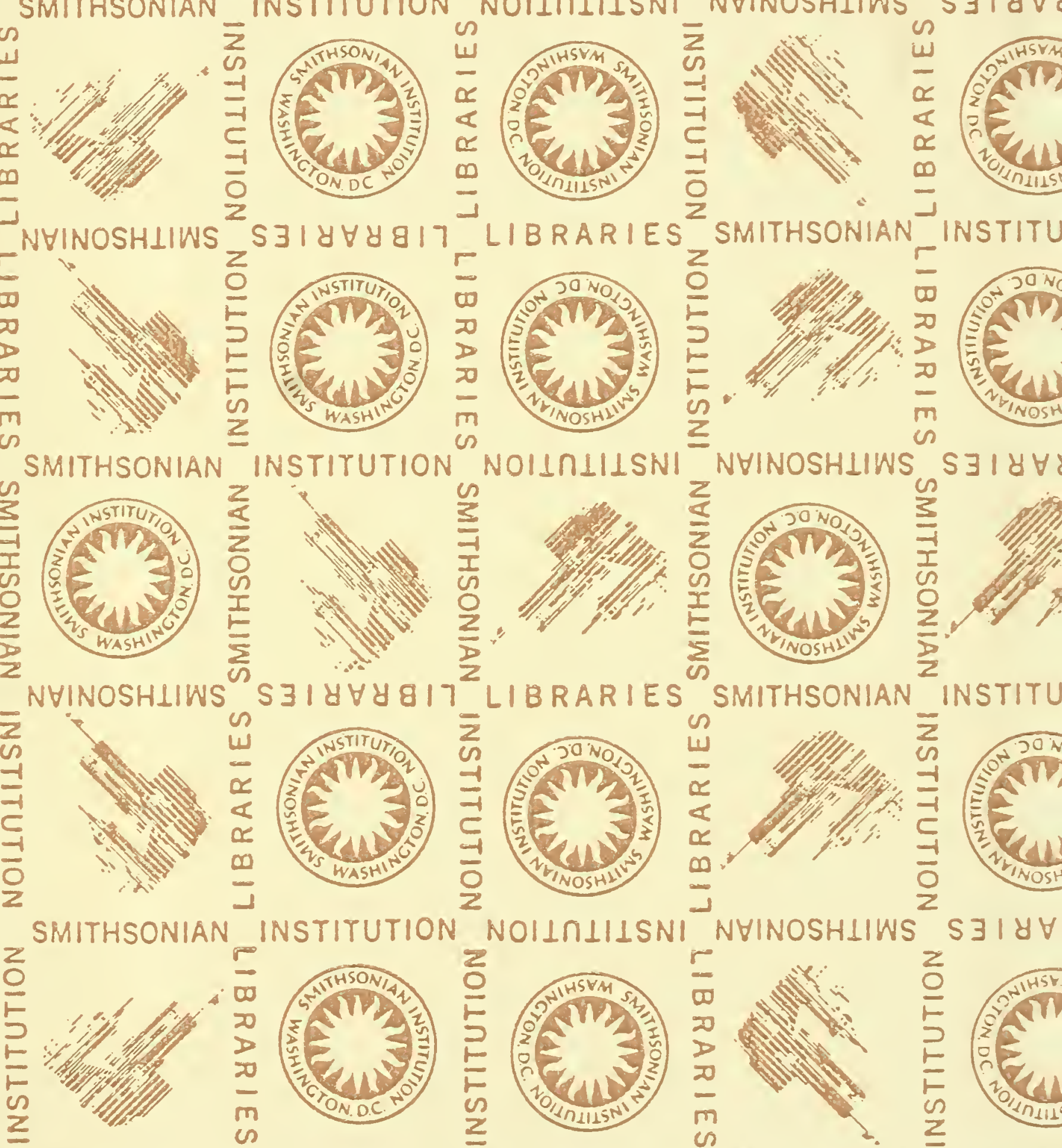

$S \exists I Y \forall$

NOILOLILSNI

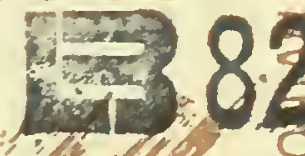

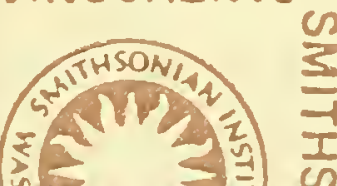

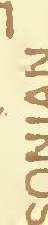


